\title{
The Concepts of Feminine and Masculine in Angus Wilson: A Critical Analysis
}

\author{
MEHOUNOU Mathias Adandé*, NOUNADONDE Sohoutou Jean, NONVIDE Issa \\ University of Abomey-Calavi (BENIN)
}

*Corresponding Author: MEHOUNOU Mathias Adandé, University of Abomey-Calavi (BENIN)

\begin{abstract}
This text addresses the possible link between the lack of critical interest in Angus Wilson (19131991), often seen as a minor or old-fashioned author over the last thirty years, and his fictional production that sometimes espouses an overtly middlebrow perspective. From this point of view, Late Call (1964) may be his most representative novel, on account of its formal humility and the ordinary character of its female protagonist. The novel boasts many feats, the most remarkable of which are: a male author's capacity to realistically evoke the consciousness of a retired woman; the relation between the description of the typical way of living of the English middle class in a new town and the heroine's identity as a former member of the rural proletariat of the 1900s; the dynamic tension between mass culture based on entertainment (television serials, light readings) and a meta-critical dimension that raises the question of the role of the "average" reader at the heart of such a standardised space.
\end{abstract}

Keywords: Middlebrow, Town and Country, Rural Novel, New Cities, Popular Culture, Virginia Woolf

\section{INTRODUCTION}

In the 1950s, Angus Wilson was thought revolutionary and scandalous. In the 1960s, he won a wide middle-brow readership. In the 1970s, he was a Booker judge and an eminent academic, but his novels were deemed out of touch. By the time he died he was so poor that appeals for his welfare were launched in the Independent and at his old university, East Anglia. Will he be remembered as an enfant terrible, an elder statesman of post-war literature, or merely as a minor talent?

Reviewing the publication of Margaret Drabble's biography of Angus Wilson in the spring of 1995, Jackie Wullschlager's sweeping account of Wilson's long career lays stress on the decline of his literary fame. Margaret Drabble's question about his legacy therefore leaves little doubt as to the fact that to her he is a minor, if significant, talent in post-war British literary culture. My purpose is to attract attention to the claim that 'in the 1960 s, he won a wide middle-brow readership.' In 1964, Angus Wilson (1913-1991), a well-established English writer in his early fifties, had already published four novels and three collections of short stories, as well as a biographical study of Emile Zola and a play. Late Call, which came out that same year, is arguably the most domestic of all his novels. Most of the scenes happen inside the home, within a narrowly circumscribed household, and those that do not are often related to the representation of un-exotic, un-scenic settings. To state that this book largely pertains to middlebrow fiction is of little help if one sticks to a catch-all definition of the term. Since the early 2000s, following up on the seminal research of a few scholars in the 1980s and early ' $90 \mathrm{~s}$, an increasing number of literary critics have demonstrated the link between the middlebrow novel and domesticity. Since 2009, a group of American and British scholars have been complicating the issue by expressing scepticism about the relevance of "middlebrow", on the grounds that as a concept it is too backward-looking, dragging "into the twentieth century phrenological debates of the nineteenth century", and continuing 'to suggest a league table of intellectual ability' whereby the middlebrow is regarded as serious but unadventurous and plodding. 'Intermodernism' has been offered as an alternative ideology concerned with diverse literary forms and multiple kinds of media. My objection however, is that 'intermodernism' is a category that contains its own demise, one may consider that all the authors, texts and genres that pertain to it belong to a historical period ranging from the 1920s to the early 1950s. By contrast, the middlebrow is open-ended and may include writers who were still alive and active in the 1970s and '80s. 
Just as problematic is the issue of gender in such fiction. Nicola Humble has famously argued that the middlebrow novel is largely a feminine category, written by women, for women readers, because addressing specifically female concerns. But more recently, the masculine middlebrow has been reinstated as a concept in its own right. How does Angus Wilson, generally looked up to as a sophisticated intellectual author, relate to the middlebrow? Wilson being a male writer, why should his work be analysed from the angle of the feminine novel? And above all how does the double issue of middlebrow literature and gender tie in with the spatial imaginary?

Wilson's fifth novel, Late Call, breaks away from the routine of the bourgeois protagonist that was to be perceived as the hallmark of his fictional manner from the late 1940s to the early 1960s. It also goes further into the potentialities of the female character, whose presence was already central in an earlier novel, The Middle Age of Mrs. Eliot (1958). Born into the rural proletariat at the very end of the nineteenth century, Sylvia Calvert, Tuffield, bears the imprint of her harsh upbringing in a deprived environment. The writer must therefore meet the double challenge of seeing and interpreting things from the perspective of someone who defines herself as not at all a clever person, and of seeing and feeling things through the eyes and mind of a woman. Of course the latter case is by no means unprecedented. One of the most famous instances of the kind is probably Henry James's The Portrait of a Lady (1881), in which the dominant point of view is that of the American-born Isabel Archer. It is certainly no coincidence that The Portrait of a Lady should be one of Meg Eliot's favourite novels (Middle Age of Mrs Eliot). The filiation is rather easy to establish here, Meg Eliot being, like Isabel, a cultivated but self-deluded dilettante (at least until her husband's tragic death). With Late Call however, it seems that Wilson needs to borrow a number of aesthetic codes from other areas of prose fiction, the rural English novel of the early twentieth century, as well as middlebrow fiction.

My contention in this article is that Late Call performs a series of balancing acts between traditionally incompatible topoi: it is a 'women's novel' whose protagonist is a woman, but written by a male author; it is an ostensibly middle-class novel paying close attention to all the minutiae of mid-century, middle-class domestic life, but in which all outward signs of family success are questioned by a deeprunning streak of Edwardian, rural and proletarian misery.

The outstanding feature of Late Call is that, apart from the Prologue, which is almost a short story unto itself, the novel is set in a New Town. It is, as a matter of fact, one of the few post-war English fictions to be set in such a place. The very first story about New Town life was also written by Wilson himself. Entitled A Flat Country Christmas, published in the collection A Bit Off the Map (1957), it evokes the depressed, disillusioned state of mind of a group of friends living in the 'shapeless waste land' of an uncompleted New Town somewhere in the East of England. In Late Call, the imaginary Midland town of Carshall, where the elderly Sylvia Calvert and her husband Arthur try to settle after Sylvia's retirement, provides Wilson with a territory as yet unexplored by literature. It seems moreover that the novelist has deliberately lowered his social and geographical range and narrowed his field of investigation. The Calverts are a simple, self-taught couple. Arthur Calvert, a mere Tommy at the beginning of the First World War, was eventually promoted to the rank of Captain, but after being badly gassed he was invalided out and hasn't been able to make a proper living ever since. Sylvia gained a different form of social promotion after the war. After toiling away on her parents' farm as a child (Prologue), she went into service at a Rectory as a girl, then became the efficient manageress of various hotels for most of her adult life. Besides being an uncharted territory in the fiction of the 1950s and '60s, New Towns, that urban phenomenon of post-war Labour Britain, are also unsuitable for romance or sensational narratives. It seems that all along Wilson's project has been guided by the careful avoidance of everything that might give its plot and characters a touch of the extraordinary, placing the emphasis instead on the commonplace and pedestrian. The 26-page long Prologue, by which we may begin the analysis of the novel, is entitled 'The Hot Summer of 1911'. It is so ostensibly set apart from the main plot that some inattentive reviewers of 1964 claimed that there was no intelligible connection between this pre-war slice of life and the bulk of the story, which takes place in the early 1960s. There is sufficient evidence, though, that the anonymous twelve-year old country girl who gets wrongly punished as a result of a misunderstanding with the smart London lady boarding with her family, is none other than the elderly Sylvia who leaves for the New Town of Carshall at the beginning of chapter one. Everything about the way Wilson has planned his novel suggests that the centuries-old dichotomy between the country and the city has become largely 
irrelevant in modern times. In 1971, writing the Introduction to a collection of photographs by Edwin Smith bearing the unassuming title England, Wilson suggests that 'England's literature is predominantly anti-metropolitan, indeed even anti-urban', and argues that "England's voice has been predominantly pastoral" (Wilson 1971, 17). Yet Wilson goes on to explain that this "backwardlooking pastoralism has been a weakening drug for England's cultural health in the days of her international decline. With the notable exception of the early nineteenth-century poet George Crabbe, literature is thus blamed for its 'refusal until only very recent times to admit to the disgusting social degradation of England's rural poor'. In choosing to focus on the predicament of a backward rural family of the 1910s in the novel's Prologue, and in placing the main centre of consciousness inside the mind of a woman who defines herself as 'a nobody', Wilson asserts his explicit concern with "the hopeless, the lost, those who don't matter" (Wilson in McDowell 1972, 78).

\section{THE COUNTRY AND THE CITY}

'The Hot Summer of 1911' is firmly anchored in the rural tradition of early-twentieth century English prose fiction. Set in the Suffolk countryside, a part of England Wilson knew well as he was to spend many years there, living in a retired cottage with only very basic amenities, the Prologue offers a purposely anti-romantic view on the realities of country life. The summer of 1911 is on record as being one of the hottest summers in contemporary history, but in terms of literary sensibility it happens to be situated at a time when the tradition of the rural novel was about to become a genre in its own right, targeted for a vast but by no means homogeneous readership; the novels of John Trevena, Sheila Kaye-Smith or Constance Holme, only a few years prior to those of the better-known writers Mary Webb, Hugh Walpole and T.F. Powys, testify to such heterogeneity. Within this tradition, antagonistic trends are to be found: rural romances, essentially conservative in tone, versus naturalistic tales in which the country is not merely a phenomenon to be enjoyed for its aesthetic, lifeenhancing qualities but first and foremost a threatened means of livelihood.

The romantic poets were most interested in the effects of the countryside on the individual person, while Wilson shares with Jane Austen a desire to investigate the city-country opposition as it affects groups and communities of people. It is not only a feeling for the country, but the integration of this feeling into the social novel, which Wilson inherits from Jane Austen.

Wilson's Prologue dramatises the interplay between these two trends, and suggests that the representation of the rural space and its inhabitants or occasional residents goes hand in hand with the definition of a reading public. The main issue in the Prologue to Late Call is the opposition between a conception of country existence based on leisure and one that, having no time for such trifles, depends on the mundane chores of farming life for its very subsistence. The first conception is conveyed through satire, the other through naturalism. The narrative initially focalises on an elegant lady from Chelsea, whose 'enlightened', liberal-minded attitude only conceals abysses of prejudice. It is tempting - but probably inaccurate - to read Wilson's style as a parody in thin disguise of that of Virginia Woolf:

Mr Tuffield, who thought no further than his cows and his wheat (or, at any rate, any other thoughts he might have were best not pondered upon), was away with the farm hand among the wheat, whose unseasonable dryness so agitated him. As to Mrs Tuffield, she thought only of doing the house and making tarts-which was a comfort as far as boarding at the farm was concerned, but she provided no interested observer. ... As to the Tuffield children, that brood of straying, whining indistinguishables that one met on the stairs like the farm's many cats and kittens, ... if they had some comment to make it would be as incomprehensible as the clucking or quacking of poultry, so broad was their dialect.

The female focaliser is a complex, double-edged weapon in this type of narrative. The language and sensibility of the smart Mrs Longmore mistakenly disrupt the already precarious order of a dying country world, the major irony of the Prologue is that Mrs Longmore's self-righteousness perceives in Mr Tuffield, then in the young Sylvia, a viciousness that springs from her own daughter Myra: 'She made me do it, Mummy. She made me take them off. She wanted me to take everything off. . . She's a horrid girl, Mummy. She's nasty'. Far more important than the feminine perception of things in this Prologue is the deep class divide whereby those who are privileged enough to be enlightened always reduce the reality of rural life into an opposition between romanticism (or a popularised form thereof) and downright ugliness: 
The door opened ... and there stood Mr Tuffield. Mrs Longmore thought if he were more like a gipsy now, a Heathcliff of a man, one could perhaps find some meaning in his violence, but as it was his flashing black eyes were set in a little dried-up, pursed-mouthed toad's face. She looked away from him in disgust.

By now we come to realise that in the Prologue, Mrs Longmore's perception is not a parody of Virginia Woolf; it is a subtly elaborate comment on the way in which, back in the early twentieth century, middle-class culture had developed a strong interest in the Brontës' works and lives in a typically 'middlebrow' manner. If we keep in mind Rubin Rabinovitz's comparative analysis of Wilson and Jane Austen, who both represent rural life in terms of the social and communal links it brings into play, we get a further sense of the irrelevance of the Brontë subtext in Late Call. Like Stella Gibbons, who in Cold Comfort Farm parodies Wuthering Heights in a more openly funny manner than Wilson, Late Call reminds us that the rationalism and clear-sightedness of Jane Austen would be more welcome than Emily Brontë's wild romanticism in the twentieth-century rural world.

Late Call is a Janus-faced novel. The Prologue is turned towards the past, both the female protagonist's past and the history of the English novel at the turn of the twentieth century. But the bulk of the narrative faces the present and possibly the future too. We are struck by the topicality of Wilson's concerns, as long as we keep in mind that the text was written in 1963 and published the following year. The early 1960s represent the 'golden age' of Britain's New Towns. What makes Wilson's choice of a New Town interesting is that on the one hand it provides a setting firmly anchored in the architectural, socio-economic reality of post-war Britain, and that on the other the utopian dimension that lies at the core of most New Town development projects is palpable throughout. The town of Carshall is a fictional place in the Midlands, loosely based on the actual towns of Telford and Corby. On the whole, it matters little whether Carshall matches the design and geographical location of its actual sister towns. It is more important to underline that the choice of the Midlands corresponds to a desire to set the narrative in a part of England that is well-known for its rather dull, un-scenic countryside. This accounts for the fundamentally unromantic landscapes that provide the backdrop of Sylvia Calvert's country walks. At this point we should bring up one of the genuinely problematic issues regarding the place of Angus Wilson in contemporary English fiction. A couple of years prior to the publication of Late Call he had declared: 'The tendency to confuse the novel with sociology seems to me the weakest aspect of modern English fiction' (The Wild Garden 137). The difficulty here is that, even if Carshall is admittedly a fictional town, the reader may struggle to find evidence that the layout of the premises isn't based on the urbanistic principles of Britain's post-war town-planners, and that its fictional inhabitants haven't been modelled on the people who actually settled there in the 1950s and '60s.

\section{Dear Mother,}

This letter is just to welcome you and Dad to 'The Sycamores'. You will find it very different here from 529 Enright Avenue. To a degree both Beth and I were unwilling to move from the old house. It was so much what we had hoped for when we came to the New Town - a spacious road, a house modern and yet neighbourly. We were also, of course, sorry to leave Craighill. It was, you know, the first district of Carshall to be completed after the Town Centre. And the first to have its own shopping centre and community hall. And we were the first residents. But the world can't exist on pioneer sentimentality. Especially the England of Mac the Knife (don't breathe these revolutionary sentiments to Dad); the whole country seems to be dying of a surfeit of nostalgia. But you'll hear H. C. on that theme when you come to live here: the children blow a whistle for what they call TFFTST (Time for Father to Stop Talking!). So, you have been warned!

Anyhow I think you'll like Melling. It's on the far side of Carshall away from the trunk road; almost into the country, but, of course, facing towards the town. 'The Sycamores' is a good modern house E. and S.T. Burman White Ltd, the people who did the new kiosks on Brighton front that were illustrated in the Guardian a month or two back with its own two acres of garden but, of course, not isolated; it conforms to the Carshall neighbourhood principles.

Harold Calvert's letter to his mother Sylvia, which goes on for several pages, invites us to read the complex relationship between literature and sociology. Harold describes Carshall as a town zoned into a set of neighbourhood units and districts whose precise function has been predetermined and planned accordingly. In this sense it contains most of the features of a typical New Town. But Wilson has a 
great sense of mimicry, and gives us a voice to listen carefully to. Through Harold's voice, 'The Sycamores' is not merely a house in a neighbourhood unit; the profile of its inhabitants may be made out according to two simultaneous perspectives: one is sociological Harold is a middle-class, Guardian-reading progressive whose family embody the ideal New Town residents. The other is more subtly at the crossroads between sociology and literature, one may detect in Harold's outbursts of domestic self-complacency a hint that this novel situates itself deliberately on the threshold of highbrow and middlebrow fiction. Late Call is indeed full of such cosy little phrases as 'TFFTST (Time for Father to Stop Talking!)' which, for all their reassuring ring, smack of self-satisfied parochialism. To pastiche Nicola Humble, we could even claim that Harold's letter 'celebrates this middlebrow paradise [of the home and the homely] unashamedly' (Humble 21). We will soon analyse how the rest of the narrative sets out to destroy such complacent claims.

\section{FEMinine AND MASCULine TERritories}

In Late Call, the one central character of classic feminine middlebrow narratives is absent: Beth, Harold Calvert's wife, died of cancer a year or so before the narrative begins. The central figure of the mother is replaced by Harold and his children Mark, Ray and Judy, who take turns in the kitchen, as well as by Sylvia herself. It soon appears, though, that everything within the domestic sphere is both in its place and displaced, or disrupted. Two sets of displacement are at work: Wilson, a male writer, appropriates a mode of writing traditionally associated with female-authored texts. This is a novel in which the chief character, Sylvia, is a woman, spending an inordinate amount of time doing the family shopping, preparing food, trying to sort out the mysteries of her son's high-tech domestic appliances the new oven's autotimer, the central heating, worrying about her furniture which is due to arrive from the hotel she has just retired from. In Harold Calvert's household, the crucial absence of the housewife means that most of the domestic chores conventionally touted as 'naturally' attractive to her fall back on the family's other members, including the males especially the males as a matter of fact:

He [Harold] laughed and, wiping the saliva from the stem of his pipe on the corner of his blue and white plastic apron, he put it away in the apron pocket. Sylvia wished that she could get used to these aprons on men. Pablo at the Palmeira had worn a plain white chef's cotton apron, as had Giuseppe before him, but they were not only professional cooks but foreigners. Here Harold had this blue plastic thing, Mark a green one, and Ray one in orange and white. And all the aprons had frills.

We can easily imagine the shudder of disgust, or contempt, that Sylvia, trained since childhood to abide by conventional sex-roles, needs to repress as she takes in the reality of her son's household (All the aprons had frills!) a house in which three men have learned to fill the gap left by the death of the wife cum mother, and to occupy spaces that are normally the preserve of females (the kitchen in particular, a crucial locus in the novel). Simultaneously and we see how Late Call continues to perform its series of balancing acts between incompatible spaces, the subtext that is most explicitly set at the core of the narrative is, of all texts, John Osborne's Look Back in Anger. Osborne's play, which is put on by none other than Harold himself, and programmed to be performed at the local school hall, with Ray Calvert as Jimmy Porter, offers a puzzling example of the vexed relationship between feminine and masculine topoi in the novel. Having achieved almost instant fame as one of the key texts of Angry Young Men literature, Look Back in Anger lends itself to the eyes and ears of Sylvia Calvert, who is invited to the amateur performance and spends most of the evening in a daze of incomprehension and disbelief:

'I say she ought to be dead,' Ray shouted. 'My God those worms will need a good dose of salts the day they get through her! Oh, what a bellyache you've got coming to you, my little wormy ones! Alison's mother is on the way!' . . She tried to attend carefully to the rest of the scene, but across her vision there ran and stumbled and fell a line of fat naked old women, some haggard and ancient as witches, others with rouge and peroxide hair and earrings, and in their eyes was the uncomprehending terror of cows going to the knacker's yard. In the background she could hear Ray's voice ranting on with its endless jeering. She knew who they were Jewesses that she had read of going to the gas chamber; yet it seemed only a terrible story when she had just read it in the Dispatch. And now suddenly Ray's voice came through as tenderly as when he explained the mysteries of the kitchen to her. 'It's Hugh's Mum. She's had a stroke... I think she's dying... It doesn't make sense at all.'

By 1963, the year when the narrative of Late Call is supposed to be set, Jimmy Porter had become a by-word for youthful maladjustment, and many British intellectuals (who would no doubt have 
refused the term 'intellectuals') had come to believe that his notorious misogyny was spearheading a battle to regain a series of rights foolishly conceded by 'progressives' to women. In Late Call, our perception of Jimmy is filtered by Sylvia, who is both a woman and a person with no highbrow pretensions whatsoever. Her response to Jimmy's offensive statements mixes up domesticity, the play's setting is after all 'a one-room flat in the Midlands' (Osborne 9; the same part of England as Late Call), and those places of contemporary history that have become part of collective memory (the gas chambers of Nazi death camps). In both cases women are the helpless victims of male torturers. Yet almost in the same breath, because the person playing Jimmy is also her grandson Ray, Sylvia is led back to the ambiguous space of the kitchen in Harold's house. In the kitchen Ray casts off his part as self-appointed 'heavy villain' and contents himself to be the charming youth that he is. The unexpected return of the comforting grandson in the middle of the play possibly explains why Sylvia's perception becomes blurred, and why the quotation referring to Hugh's mum's stroke is inaccurate.

The relationship between domestic and political spaces in Late Call is another difficult issue. Middlebrow fiction was long held to be the preserve of the representation of domesticity. Yet a few interestingly dissenting voices have expressed the view that the feminine middlebrow can also become a means of representing public, political debates. What about Late Call? Throughout the narrative, Sylvia shies away from political involvement. Wilson goes to a lot of trouble to remind us that his protagonist is not politically conscious, and that most of the social, urbanistic debates and conflicts are clearly over her head. By imagining himself into the mind and body of Sylvia Calvert, Wilson stresses the feminine predicament in terms of how much space, if any, a woman long past her prime is to be allotted and how much visibility she can hope to be granted.

She turned to the Daily Mail. Answer to last week's puzzle; it is probably easier to answer the question by eliminating those whom you would not save. First, sorry for her, the Captain's wife will have to go overboard. She's fifty-five. Her children are all grown-up. She's not particularly bright, she doesn't even get on very well with the Captain. In fact their relations if anything rock the boat. In any case she's had her life.

Conflating the literal and figurative meanings of the phrase 'to rock the boat', Sylvia is prodded by the newspaper into (mentally) jumping overboard, on the grounds that she is a superannuated and superfluous non entity. A similar situation occurs in an early short story, 'A Little Companion', whose protagonist is a middle-aged spinster eaten up by guilt at feeling useless in the world she lives in Late Call, a novel that constantly flirts with middlebrow fiction, subverts its most conventional codes then, first by 'killing' the housewife before the opening chapters, then by insisting on the fact that the two remaining female figures are not really in the picture: Judy, Harold's daughter, turns out to be a dreadful snob who likes to spend as much time as possible away from home and to stay with an aristocratic French family near Tours; Sylvia, who is willing to help, is soon made to realise that the only function of her domestic tasks is to keep her busy.

Many pages of the novel are devoted to Harold Calvert's fight to save Goodchild's Meadow, a fallow field that runs through Carshall's town centre, from being sold and developed as a medium-priced housing estate. His initial motives are commendable enough, though he voices them in that habitual pompous way of his: "That Carshall people should have good farmland well-farmed running through the centre of their conurbation lies at the basis of everything the New Towns stand for". Aware of her own limited comprehension of the issue, Sylvia remains cautiously in the background (121-123), and is too busy anyway paying off the debts of her feckless husband Arthur, who has been borrowing money from all Harold's friends. Before long however, Harold's losing battle turns into an obsession which brings about his mental collapse. Once again, the relationship between masculine and feminine topoi may be read in two possible ways. We can regard Sylvia as a self-effacing figure, whose chief role consists in sorting out the mistakes of her husband and son while 'knowing her place' all along. We can also take into account the fact that the double collapse of her husband and son does not imply that Sylvia is to become sole mistress of her small domestic kingdom at the end of the narrative. On the contrary, after Arthur's final stroke and death, and after her son's breakdown, she is in a position to realise that Harold's knowledge of children so much advertised in his best-selling book of cognitive sociology, The Blokes at the Back of the Class is 'all theory'. Moreover she is herself ready to leave 'the home' and look for a place of her own. We should insist here on the ironic twist in the Angry Young Men subtext: Ray, who played the aggressively heterosexual character Jimmy Porter, reveals 
to his father that he is gay, and that he does not belong in the New Town community. Harold stiffly refuses to understand him and rejects him.

\section{Mapping Culture in late Call}

On the map of audiences and markets, the middlebrow is literally the middle: the centre ground, a large and influential area of cultural production. On the scholarly map, by contrast, the middlebrow has traditionally been located at the margin: in an area at the edge of the canon, or beyond its reach. (These spatial metaphors are very telling.)

In Late Call, the relationship between the spatial imaginary and the 'battle of the brows' does not only take the form of an almost literal representation of domesticity versus the outside world in a Midland New Town. A whole cultural terrain is also thoroughly explored on a meta-linguistic level. Sylvia Calvert, feeling depressed in her son's comfortable but rather impersonal home, becomes addicted to certain forms of escapism. The entertainments she enjoys most in her retirement are those of the midtwentieth century, i. e. mass-produced televised soap operas. She has also a subscription to the Public Library (137 and 188), where she borrows novels or autobiographies. Interestingly Sylvia fancies mostly light fiction and historical romances, which testifies to her lowbrow tastes. All the authors and titles mentioned in the narrative are fictitious, and the sometimes long extracts from Wardress Webb (Sylvia's favourite serial, 178) have been invented by Wilson himself. This goes to show that Wilson's approach to culture is unlike that of Q. D. Leavis in Fiction and The Reading Public, whose anthropological method (Leavis 1932, xiv) is based upon real figures and quotes real names and titles. While Q. D. Leavis polemically demonstrates the danger of the 'democratisation' of literacy on the grounds that it only furthers the commercial interests of big publishing firms without promoting the intellectual advancement of the masses, Angus Wilson takes a far less elitist stance Sylvia is not highly educated, she may like reading light fiction but she is perceptive enough to know when such writing becomes too formulaic:

She buried herself deep in A Winter's Holiday. It was all to do with a red-haired girl at an office who'd been ill, after a broken engagement. She got an anonymous present of $£ 250$ with which to take a winter holiday abroad. . . . To her surprise, her employer, who was usually a grouchy sort of man, urged her to go, and even recommended a holiday in Sicily. . . . Just as the heroine was feeling really strong again and getting a bit restless because there were very few visitors in Sicily at that time of the year ... who should turn up but her boss? It was he who had sent the money, it seemed. Sylvia wished she hadn't borrowed quite so light a novel. She made herself read on. The boss hadn't intended to follow the heroine there at all; but he was so unhappy, his wife who had always been a bad lot was in a home for drunkards, and obviously he had fallen in love with Yolande, that was the heroine's name. And quite reverently without any attempt to press his love upon her, although she had guessed, he set himself to give her a wonderful time motor trips to Mount Etna and wonderful fish lunches on terraces covered in morning glory. . . . Sylvia shut the book. She reminded herself not to get any more of Martin Home's. They had become too silly.

Although the plot of A Winter's Holiday is a crude parody of the kind of sentimental novels published by Harlequin Books, the point to keep in mind is that Sylvia is not a highbrow, and that her rejection of the setting's facile exoticism is not prompted by her superior experience, i.e. by her ability to decode clichés ('wonderful fish lunches on terraces covered in morning glory'). On one occasion she even informs another character that she's 'never been out of England'. We now realise how Sylvia herself, on her diegetic level, performs a balancing act between her very limited knowledge of worlds outside or beyond her own narrow sphere, and her impatience with everything hollow and highfalutin. For her birthday, Harold invites her, Arthur, their grandchildren and some neighbours to Chen Fu's, the local Chinese restaurant. She can at once perceive the social and cultural gap between her and Arthur and the rest of the party: 'After their earlier treatment of Arthur it made Sylvia feel wild. Very much the little ladies and gentlemen they all were with their posh foreign restaurants!' Refusing to adjust to the unfamiliar context, Sylvia and Arthur defiantly announce 'their intention of ordering from the side of the menu headed, "English Fare""

\section{CONCLUSION}

Neither wholly taken in by the mechanical, formulaic patterns of mass entertainment nor willing to adapt when she feels above her station, Sylvia Calvert is a typical middlebrow heroine, living in the mid-century middlebrow space of a British New Town. Many readers, especially female ones, 
therefore identified with her humble origins and ordinary lifestyle. In terms of readership and thematic concerns, Late Call is admittedly the most middlebrow of all Wilson's novels. Yet it is crucial to underline that Wilson is not middlebrow because his style is mediocre or because he turns out 'run-ofthe-mill' novels - such an implication would reduce the middlebrow to a merely aesthetic value judgment, but because middlebrow fiction is literally obsessed with the representation of middle-class aspirations, and because the middle class, into which Wilson was born, is the environment he knows best, and whose cultural habits he knows most intimately.

Interestingly, there is no 'genius loci' in Late Call. The protective spirit is ineffective in a home that, for all its progressive mottos, excludes those who don't belong to the closed New Town community. As Ray, who has come out, puts it in his letter to his brother Mark:

It's only London that'll work for us. Anyhow the point is I've got to get out now. And that leaves you and Gran to hold the umbrella over Dad. And he needs it badly at the moment. As I told Gran he'll never come in out of the rain himself.

The 'genius loci' is not attached to any particular place; it can only be found among people.

In this novel Wilson keeps within the formal confines of middlebrow English fiction, and the New Town device suggests that such fiction is unable to accommodate those who are forced to live on the margins of mainstream society. This latter point, however, begs the key question of the link between mainstream and middlebrow cultures. It would be both unfair and inaccurate to conclude that the middlebrow is by definition attached to a conservative, conformist world-view. As a matter of fact, middlebrow fiction of the interwar and post-war period provides much evidence to the contrary. If the setting of Late Call tends to homogenise people's lifestyles then, its textual space is far more open to individual reflection and to alternative forms of expression.

\section{REFERENCES}

[1] Beauman, Nicola, A Very Great Profession: The Woman's Novel 1914-39, London: Virago, 1983.

[2] Bluemel, Kristin. Literary Culture in Mid-Twentieth-Century Britain, Edinburgh: ed., Intermodernism , Edinburgh UP, 2009.

[3] Bracco, Maria, 'Betwixt and Between': Middlebrow Fiction and English Society in the Twenties and Thirties, Melbourne: U of Melbourne P, 1990.

[4] Brown, Erica, and Mary Grover,. The Battle of the Brows, 1920-1960, Basingstoke: Palgrave Macmillan, 2012, eds., Middlebrow Literary Cultures.

[5] Calvaliero, Glen, The Rural Tradition in the English Novel, 1900-1939, London: Rowman \& Littlefield, 1977.

[6] Drabble, Margaret, Angus Wilson. A Biography, London: Secker \& Warburg, 1995.

[7] Gibbons, Stella, Cold Comfort Farm (1932), Harmondsworth: Penguin, 1956.

[8] Hammill, Fay, Afterword to Middlebrow Literary Cultures. The Battle of the Brows, 1920-1960, eds. Erica Brown and Mary Grover, Basingstoke: Palgrave Macmillan, 2012, 232.

[9] Humble, Nicola, The Feminine Middlebrow Novel 1920s to 1950s. Class, Domesticity, and Bohemianism, Oxford: O.U.P., 2001.

[10] James, Henry, The Portrait of a Lady (1881, rev. 1908), New York: Norton, 1995.

[11] Leavis, Q. D., Fiction and the Reading Public (1932), London: Chatto \& Windus, 1965.

[12] Lehmann, Rosamond, Dusty Answer (1927), Leipzig: The Albatross, 1937.

[13] Macdonald, Kate, ed., The Masculine Middlebrow, 1880-1950. What Mr Miniver Read, Basingstoke: Palgrave Macmillan, 2011.

[14] McDowell, Frederick P. W, 'An Interview with Angus Wilson', The Iowa Review 3 (Fall 1972): 77-105.

[15] Maslen, Elizabeth, 'The Case for Storm Jameson', eds. Marina MacKay and Lindsey Stonebridge, British Fiction After Modernism, Basingstoke: Palgrave Macmillan, 2007, 33-41.

[16] _ 'A Cassandra with Clout: Storm Jameson, Little Englander and Good European', ed. Kirstin Bluemel, Intermodernism. Literary Culture in Mid-Twentieth-Century Britain, Edinburgh U.P., 2009, 2137.

[17] Wilson, Angus, ‘A Little Companion' (1950), The Collected Stories of Angus Wilson, London: Paladin, 1989, 185-195.

[18] - 'Sense and Sensibility in Recent Writing', The Listener 24 August 1950: 279-280. 
[19] _ 'A Flat Country Christmas' (1957), The Collected Stories of Angus Wilson. London: Paladin, 1989, 340-47.

[20] — The Middle Age of Mrs Eliot (1958), London: Faber \& Faber, 20

\section{AUTHOR'S BIOGRAPHY}

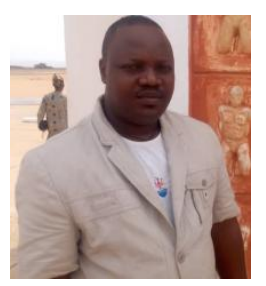

Dr Mehounou Adandé Mathias, Enseignant chercheur à l'Université d'AbomeyCalavi.(Bénin)

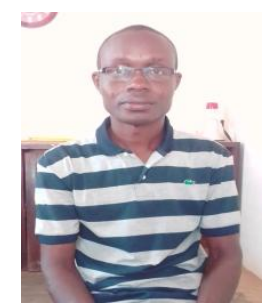

NOUNADONDE Sohoutou Jean is doctor to be of University of Abomey-Calavi in British studies.

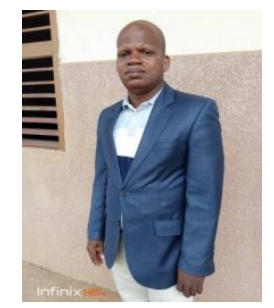

NONVIDE Issa is doctor to be of the University of Abomey-Calavi in British studies.

Citation: MEHOUNOU Mathias Adandé, et.al. “ The Concepts of Feminine and Masculine in Angus Wilson: A Critical Analysis". International Journal on Studies in English Language and Literature (IJSELL), vol 6, no.9, September 2018, pp. 68-76. doi:http://dx.doi.org/10.20431/2347-3134.0609008.

Copyright: (C) 2018 Authors. This is an open-access article distributed under the terms of the Creative Commons Attribution License, which permits unrestricted use, distribution, and reproduction in any medium, provided the original author and source are credited. 